\title{
JPPB Review
}

Received on June 11, 2015/ Approved on October 20, 2015 Responsible Editor: Maria Dolores Sánchez-Fernández, Ph.D. Associate Editor: Manuel Portugal Ferreira, Ph.D.

Evaluation Process: Double Blind Review pelo SEER/OJS

\section{International Journal of Professional Business Review}

\section{THE FOUR DIMENSIONS OF KNOWLEDGE: COGNITIVE, CONNECTIONIST, AUTOPOIETIC AND INTEGRAL. ADVANCING THE UNDERSTANDING LEARNING}

\begin{abstract}
The question of knowledge permeates our society since the days of the Greek Philosophers. According to some "knowledge" is what allows men to solve their everyday problems. This article goal is to conceptualize knowledge regarding the individual learning of the human being: in the eyes of the cognitivists; following the optics of connectionism; and in accordance with the autopoietic approach. By way of an epiphany we discuss the knowledge in an integrated vision that understands each of the three concepts as aspects of the same reality. Therefore, the methodology used was a descriptive exploratory research, a qualitative approach, which allowed, in the end, infers some considerations on the question of knowledge in a broader and more comprehensive approach.
\end{abstract}

Keywords: Knowledge, Knowledge Concepts, Knowledge Dimensions, Knowledge Autopoietic Vision, Cognitive.

\section{AS QUATRO DIMENSÕES DO CONHECIMENTO: COGNITIVISTA, CONEXIONISTA, AUTOPOETICO E INTEGRAL. AVANÇANDO NA COMPREENSÃO SOBRE A APRENDIZAGEM}

\section{RESUMO}

A questão do conhecimento permeia nossa sociedade desde os tempos dos filósofos gregos. Segundo alguns o conhecimeto é o que permite que o homem equacione os problemas do seu cotidiano. O objetivo deste artigo é conceituar o conhecimento referente ao aprendizado individual do ser humano inicialmente: na episteme dos cognitivistas; dentro da ótica dos conexionistas e na abordagem autopoiética. A título de uma epifania discute-se o conhecimento numa visão integral que enxerga os três conceitos como aspectos de uma mesma realidade. Para tanto, a metodologia utilizada foi uma pesquisa descritiva exploratória, numa abordagem qualitativa, o que permitiu, ao final, inferir algumas considerações sobre a questão do conhecimento em uma visão mais ampla e integral.

Palavras Chave: Conhecimento, Conceito de conhecimento, Dimensões do Conhecimento.

Francisco Fialho ${ }^{1}$

Andreia de Bem Machado ${ }^{2}$

Daniela Fanucchi Moussa ${ }^{3}$

\footnotetext{
${ }^{1}$ Universidade Federal de Santa Catarina - UFSC, Brasil

Email: fapfialho@gmail.com

${ }^{2}$ Universidade Federal de Santa Catarina - UFSC, Brasil

E-mail: andreiadebem@gmail.com
}

${ }^{3}$ Universidade Federal de Santa Catarina - UFSC, Brasil 


\section{LAS CUATRO DIMENSIONES DE CONOCIMIENTO: COGNITIVA, CONEXIONISTA, AUTOPOIÉTICO E INTEGRAL. AVANCE DEL APRENDIZAJE ENTENDIMIENTO}

\section{RESUMEN}

La cuestión del conocimiento impregna nuestra sociedad desde los tiempos de los filósofos griegos. Según algunos, el conhecimeto es lo que permite que el hombre trata de resolver los problemas de su vida cotidiana. El propósito de este artículo es el de conceptualizar el conocimiento con respecto a la de aprendizaje individual del ser humano inicialmente: la episteme de la cognitiva; en la perspectiva del enfoque conexionista y autopoiético. A modo de una epifanía discute el conocimiento en una visión integral que ve a los tres conceptos como aspectos de una misma realidad. Por lo tanto, la metodología utilizada fue un estudio exploratorio descriptivo, un enfoque cualitativo, que permitió que, al final, inferir algunas consideraciones sobre la cuestión del conocimiento en una visión más amplia y más completa.

Palabras clave: Concepto del conocimiento del conocimiento, conocimiento Dimensiones.

\section{DIMENSIONS OF KNOWLEDGE}

\section{Introduction}

"El verdadero pintor es aquel que es capaz de pintar escenas extraordinarias en medio de un desierto vacío. El verdadero pintor es aquel que es capaz de pintar pacientemente una pera rodeado de los tumultos de la historia." (Salvador Dalí)

The Cognition Sciences are connected to the work of the mathematical, logical and computer scientist Alan Turing and his experiments related to intelligence. The idea of this scientist was to create a machine that simulates the mind of a baby, that is, the human being at birth and submit him to an educational process. The universal Turing machine, created in 1936, inspired John von Neumann and others. Subjected to cultural persecution because of his sexual orientation, Turing committed suicide in 1952, before completing his research on human knowledge.

Two currents arise at this period. One who defends a symbolic architecture, classical cognitive vision and another connectionist. The symbolic architecture, cognitive, follows the development of the first computers. Ada Lovelace, daughter of Lord Byron, already predicted in the nineteenth century that Babbage's machine, great-grandfather of today's computers, could operate not only with numbers, but also with any kind of symbols. The knowledge would be represented by symbols within the human mind and learning would be building (empiricists) or awakening (idealists) symbols ${ }^{4}$. This cognitive view of knowledge will serve as inspiration for the production of the Neumann digital machine and the Expert Systems.

In "The Mind's New Science: A History of the Cognitive Revolution", Howard Gardner tells the story of cognitive sciences. In the Hixon Symposium dated 1948, in which John von Neumann, Warren McCulloch and the biologist Karl Lashley lectured, the way in which the Nervous System controls the behavior was discussed.

\footnotetext{
${ }^{4}$ In Plato the knowledge is innate (learn is to remember). For Aristotle the knowledge is acquired.
} 
"I define Cognitive Science as a contemporary, empirically based effort to answer long standing epistemological questions - particularly those concerned with the nature of knowledge, its components, its sources, its development, and its deployment." (op. Cit., 1985)

The Macy Jr. Foundation is always mentioned when speaking of a Cognition Sciences' history. From 1946 till 1953, ten meetings were held and each lasted for two days.

The causes and responses of the mechanisms associated to the biological and social system were the main issue: "Circular Causal and Feedback Mechanisms in Biological and Social Systems". The presence of scientists from different fields of knowledge led to an initial difficulty in the work, mainly ragarding the communication between the participating members, each speaking in the language of their own disciplines. For the dialogue to take place it was necessary to learn these new languages, which required time and conviviality between the participants.

In these meetings researchers as Gregory Bateson, Margareth Mead, Warren McCulloch, Norbert Wiener, John Von Neumann, Walter Pitts, Kurt Lewin, Heinz Von Foster and Warren McCulloch gathered. These studies led to concepts that founded all modern science. One of the fields inaugurated is what we know today by cybernetics.

How does the brain work from the error using the information from there obtained to, later, to achieve this hit? The founding fathers of cybernetics were John von Neumann, Nobert Wiener and Warren McCulloch.

(...) Unlike the behaviorists' view that brains functioned as a result of external stimuli, these researchers propose that the brain would be like a connectionist formed by connections between cells, in a closed system in itself. (FIALHO, 2011, p.16)

Related to McCulloch's studies, there are those by Humberto Maturana and Francisco Varella initially during the 1970s to explain the difference between living beings and machines (From Machines and Living Beings). Both produced the theory of autopoiesis. "All doing leads to a knowledge and all knowledge is a creation. We do not know the world, but we create to attempt to know it and we (re) create in the process" 5 .

The theory of autopoiesis explains knowledge as emerging from the network onnections that bind and complete each other, in other words, a system of complex connections that unite and relate one another. According to Esteban-Guitart and Moll (2014) knowledge is the result of experiences lived by people, including their social interaction. Knowledge is shared through this relationships' network and it is checked by this same network.

As it can be seen, the cognitive science is interdisciplinary, using different lenses, in other words, of the different perspectives of the disciplines in order to understand thereof. Therefore, This article aims to conceptualize the knowledge regarding the individual learning of the human being in the cognitive view; on the perspective of the connectionists; and within the autopoietic approach. By way of an epiphany the knowledge in a global view is discussed which sees the three concepts as aspects of the same reality.

\footnotetext{
${ }^{5}$ MATURANA, Humberto. A árvores do conhecimento: as bases biológicas da compreensão humana. São Paulo: Palas Athena, 2001.
} 


\section{Knowledge In View Of cognitivists}

No power, a little knowledge, a little wisdom, and as much flavor as possible. (Roland

Herbert Alexander Simon was one of the first to study the issue of problem solving through creative thinking. For this author the scientific research process is related to the discovery situations.

Simon studied the issue of invention related to cognitive processes linked to the act of thinking of the human being leading it to problems resolution imbued with in their historical, cultural and social context.

This situation can be represented, according to this author, through the computer, because it is the only one who can simulate the procedures of the human psyche: "to imitate the human thought processes such those that are actually produced in the human brain on the problems' resolution (and other cognitive activities and from any type)" (SIMON, 1977: 265).

To develop new ways in which the human being can acquire knowledge it is necessary to understand how this process happens inside our brains. Simon explains: "only a deeper understanding of how the human mind works can help us find some means to improve them " (1984: 116).

For this author discovering is something rare. There are no differences between the resolution of our daily problems of our day to day or problems of scientific order in a research setting. Innovation has no secrets, it occurs through simple elements experienced in our reality "the secret of innovation is that there is no secret. It is accomplished by making complex combinations of simple elements play" (SIMON, 1960: 69).

Simon (1984) proposes that everything can be explained by the knowledge structures and by a selective amnesia which are at the basis of the procedure to solve problems. These are linked to the issues related to our short and long-term memory.

The first mechanism (short term memory) work without taking his eyes off to not lose the way, and the second (long-term memory) rejects the finished. The second stores its rejections in disorder. The researcher is guided by a map of poorly maintained hikes in immediate memory. When he is found in front of an impasse, he can leave this way and forget the walk maps initially adopted. When exploring another way, he keeps in its permanent memory the stored information at the first attempt as rudimentary knowledge of the initial walk map; new symbolic structures can then rearrange otherwise these elements and make room for new walking maps. (MACHADO, 2010,p. 2)

Another point in Simon's conception is concerning the discovery that the knowledge acquired by the discovery occurs through psychological processes and that are the same for the first and to reinvent the question

" This is why, the Bacon program, using the same data as those that the early inventors had (Kepler and Ohm) get to the same laws, he (re) discovers. Bacon demonstrates that the organization of the processes necessary to make scientific discoveries is essentially the same as that required by the majority of problem solving systems " (SIMON, 1984: 14)."

Knowledge is accomplished through discoveries of theoretical processes of cognitive science which permits the human being to discover through perception, or cognition a way to explain the world in the best possible way, in other words, the representation of the world around him the most accurately possible. 
In this approach knowledge is conceptualized as a grouping of world representations, formed by a number of circumstances which compose our daily lives. Therefore the knowledge is the result of our sensory experiences, an explanation / representation of the reality that surrounds us.

The first calculators operated on numbers. Ada Lovelace in a Pythagorean epiphany already predicted that it would be possible to operate on any type of symbols. Computers could write poetry or compose music (as they already do), but they would never be able to display intelligence.

The Lady Lovelace's argument was refuted by Turing. Will symbolic architecture machines be able to become intelligent? For those who defend a connectionist architecture, the answer is no.

The symbolic machine has inputs and outputs. Symbols are processed and new symbols are created.

To emulate any brain simply put in the memory existing symbols and copy programs that it uses to process external symbols and build new symbols.

If this idea were true, today we would already have intelligent machines.

\section{Knowledge In The Connectionists' view}

The books know by heart thousands of poems. What a memory! (Paulo Leminski)

John McCarthy and Marvin Minsky organized in Darthmouth College, in 1956, a conference that would have marked the beginning of "Artificial Intelligence", as science. At the time of the "Expert Systems" it was believed that symbolic machines could become intelligent. John Von Neumann, the creator of the current computer architecture, noticed before his death, in 1976, that, back then, the architecture of the human brain is different from computers': "logic will have to undergo a pseudomorphosis to neurology"6

Proponents of the connectionist's view insist that it is not enough to just operate on symbols to build new symbols, but it is necessary to imitate the human brain architecture. The brain is, undoubtedly, digital, but not only digital. We are analog machines able to operate on the mystery and, from it, extract heuristics and algorithms.

Douglas Hofstadter (1979) in his book "Godel, Escher and Bach" claims that in order to reach the Artificial Intelligence one must understand how the human imagination occurs.

Walter Isaacson (2014) $)^{7}$ explains the concept in a humorous way: "Ask Google an objective question as: "What is the depth of the Red Sea?", and he will instantly answer "2211" meters, something that not even your smartest friends would know. Ask it an easy question as "does an alligator know how to play basketball?", and Google will not have a clue, even though a two years old child would able to answer, after laughing a lot".

How to create machines with sense of humor and able to show emotions? The human brain is not only digital and analog, but it works in a distributed manner as a network within networks.

Connectionist machine functions as a parallel computer composed of billions of neurons (for now the machines are at the granularity of millions).

The network learns from its operating, adjusting their synapses to find appropriate responses.

Cognitive wealth takes place in interactions. We are networks within networks, in the learning process.

\footnotetext{
${ }^{6}$ The Computer and the Brain. New Haven: Yale University Press, 1958 p.80

${ }^{7}$ Os Inovadores. Companhia das Letras, 2014
} 
Image 3. The connectionist machine

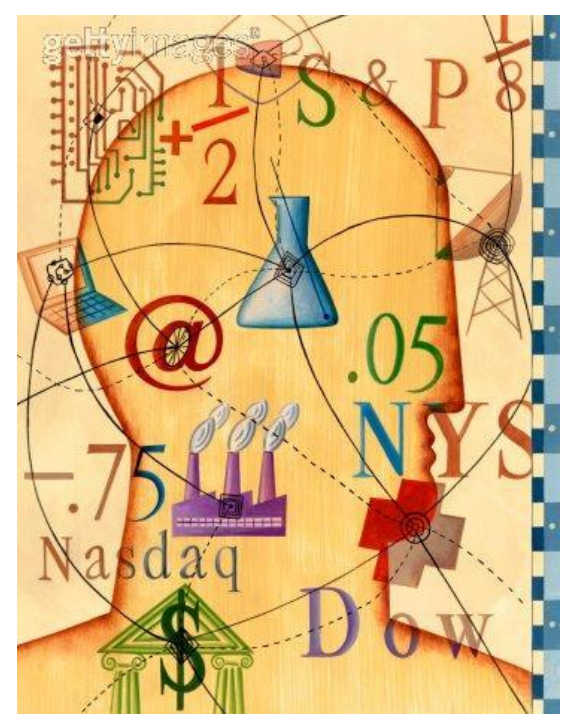

https://paideiablog.wordpress.com/2010/03/09/

\section{Knowledge in the Autopoietic Vision}

Socrates, my master, is my friend but a greater friend is truth. (Aristotle)

Maturana and Varela established the autopoiesis theory, which is based on the idea that living things manufacture themselves. While allopoietic machines produce "outward, for the world", autopoietic machines produce to themselves. These scientists propose to understand the autonomous nature of biological organization and understand how the identity can be maintained throughout the evolution that generates the diversity ${ }^{8}$.

In the book "Tree of Knowledge" Varela (1989, p. 219) summarizes the two fundamental theses that had great impact after 1946.

\begin{tabular}{|c|c|c|}
\hline & Heteronomous systems & Autonomous systems \\
\hline $\begin{array}{c}\text { Basic logic } \\
\text { operation }\end{array}$ & correspondence & coherence \\
\hline $\begin{array}{c}\text { Type of } \\
\text { organization }\end{array}$ & $\begin{array}{c}\text { Input / Output } \\
\text { transfer functions }\end{array}$ & $\begin{array}{c}\text { operational closure } \\
\text { own behavior }\end{array}$ \\
\hline Interaction Mode & $\begin{array}{c}\text { a world given with instructions } \\
\text { and representations }\end{array}$ & a world emerging of meanings \\
\hline Theoretical basis & John Von Neumann & Norbert Wiener \\
\hline
\end{tabular}

Chart 1 . The autonomous and heteronomous views in many fields Source: A Árvore do Conhecimento

\footnotetext{
${ }^{8}$ O trabalho de Humberto Maturana e Francisco Varela por Edla Faust Ramos
} 
Maturana brings two important contributions. First of all, he rejects the conception of intelligence as an independent individual attribute. Intelligence is not an individual capacity, but relational. Our action, in the fabric of social relations, reveals our intelligent behavior. Intelligent behavior is contextual, it manifests itself in the context. The intelligent behavior manifests itself in the relation with the other - "consensual domain" - and with the environment - "ontogenetic adaptation". It takes place, therefore, through the flexibility and consensuality: 9

Manguel mentioned by Paulo Freire ${ }^{10}$ already said that we are letters in the pages of a great book and that, when we change, we modify this book. Maturana talks about a walker on the beach. At the end of the walk nor the beach nor the walker are the same any more.

In the autopoiesis' theory what matters is not the representation, but the action. Piaget had already said that his theory was a gestaltkreis. Not just a "whole", but a "whole" on which it operates to get a result. Knowing is creating. Knowing is a process and not a "thing".

The universe is a quantum and complex hypertext meaning network. We are a network within this network, changing, modifying the networks: "The whole" of which we are part of.

Knowing is not individual, but collective. We are in continuous interaction with others outside of ourselves and others within us.

The autopoietic machine has nor inputs nor outputs. It works through internal disturbances.

For Maturana, the term "autopoesis" means the "center of the constitutive dynamics of living beings ". Living beings are at the same time independent and dependent. Therefore, it is a paradox.

Our internal famines force us to open ourselves to the world intentionally, in search of something to quench hungers. This is an "active" and not "reactive" machine.

Image 4. The autopoietic machine

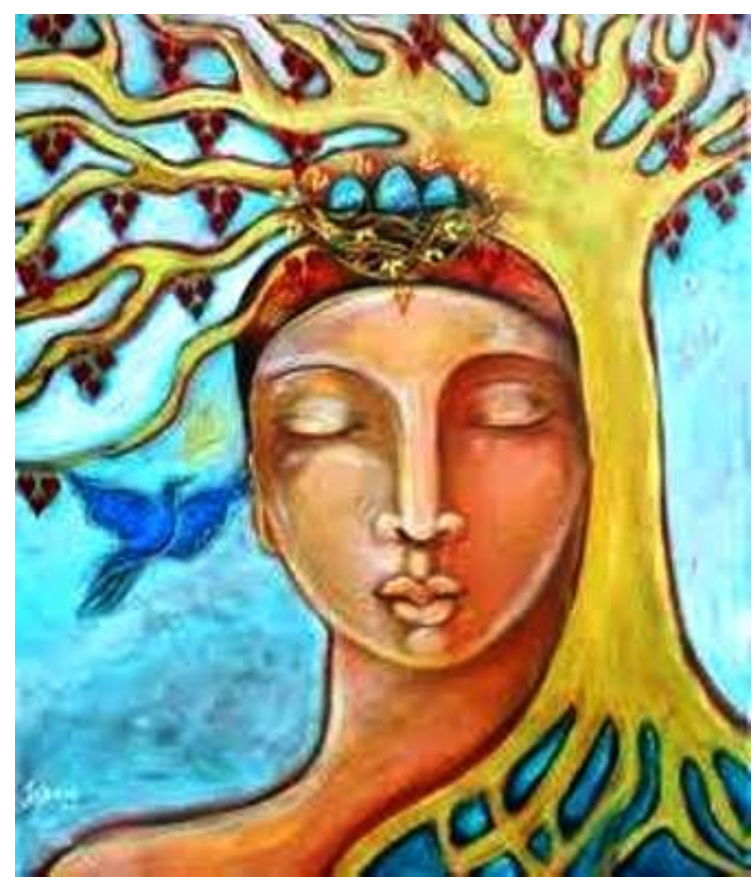

http://cristianegantus.blogspot.com.br/2012/10/autopoiese-cultura-e-sociedade-por.html

\footnotetext{
${ }^{9}$ CUNHA FILHO, José Leão: A certeza da incerteza educa. http://www.humanitates.ucb.br/3/certeza.htm ${ }^{10} \mathrm{FREIRE}, \mathrm{P}$. A importância do ato de ler em três artigos que se completam. São Paulo: Cortez, 2005.
} 


\section{Knowledge In An Integral Vision}

It is stupid to ask the gods for what one can achieve alone. (Epicurus)

Baruch Spinoza already claimed in the sixteenth century that the action of God is a necessary manifestation of his essence. It is a being which causes to itself, which produces itself. Here it is, surely, what three centuries later would be called self-production, says Humberto Mariotti ${ }^{11}$.

Piaget says that the child explains the man. The first type of reasoning, a kind of protoreasoning, is the discovery by accident, which occurs, practically, from the beginning of the baby's life. The way in which knowledge manifests is best explained by the autopoiesis theory. The sensorimotor schemas engine of the type < context: operator: result > show that assimilation is, above all, action in the world. The child at birth behaves as an autopoietic machine.

By the age of two, for the child, there are two planes of reality: the toy plane, in which the world's data are assimilated to the I of the child, with the dominance of fantasy, and the observation plane, when accommodation occurs, that is, the I of the child is subjected to data from the outside world. Neural networks began their learning process Synapses are established and children learn by imitation, behaving as a connectionist machine.

Immanuel Kant, in the eighteenth century, in his book Critique of Judgment, refers to the organism as a whole which produces itself. Plotinus, exponent of neoplatonism philosophy, had already spoken in auto- causality towards self-production. Darcy Ribeiro used to say that the human being is being built in language.

If at birth we produce ourselves by action, by language, we transform into symbols to interact with other symbols in search of meaning. The symbolic machine is established. The culture will little by little establish the symbolic machine as dominant. The logic starts to prevail over emotion. Learning becomes "unfunny".

Between seven and eleven years the intellectual egotism will gradually giving way to the logical thinking. Symbolic schemes become, now, concrete conceptual schemes, true mental schemes in which reality becomes structured by reason and not by the egocentric assimilation. We look, more and more, like the symbolic architecture machines.

The child learns to represent the world through signs and symbols, in other words, images and words. He constantly rearranges his picture of the world through imaginary toys, conversation, inquiry, listening and experimentation. Then, the internalization of action schemes begins, in the form of representations. At the age of five, more or less, representative organizations are established, whether as static configurations, or under an assimilation to the action itself.

With the formal operational structures, that begin to form at about eleven or twelve years, we reach the stage of the development process in which the operations are freed from the psychological context of the actions of the subject. Knowledge goes beyond the real to be inserted into the possible and to relate directly to the possible to the necessary, without the necessary mediation of concrete. The work is on hypothesis and not on objects.

The child studied by Piaget is not the same today. The child of this new millennium navigates through networks, he learns to build knowledge through interaction not only with human, but also with devices.

Before, the end of education was the transformation of the human into machine. We learned to operate over symbols. The linguistic intelligence and logical-mathematical were

${ }^{11}$ www.iiac.cnrs.fr/CentreEdgarMorin/spip.php? Acessado em 01/05/2015 
privileged. By the end of the educational process we were invited to exchange our humanity by the cold logic of calculations and predictions.

In contrast to this reality of the past, technology comes virtualizing the world. In the past the interactions were few and limited to a single cultural horizon. The internal neural networks reproduce themselves, now in cyberspace. We are neurons of a huge collective brain. All the time we are extending synapses to new and charming worlds.

We talk about a community of practice, places where there is a "situated learning", which emphasizes a social and cultural-historical understanding that understands the person in his totality, in his relationship with the community where he is located, and not as a being who submit himself to the role of recipient of a body of knowledge about facts related to the world (SENSE; BADHAM, 2008).

Jane Lave (1991) states that any form of knowledge lies at the power to negotiate the meaning of the past and the future, to build the meaning of the circumstances of the present. It increases also the need to locate where learning occurs, contextualizing it and placing it, presenting its social, historical, cultural, economic and political peculiarities, such that the analyzed circumstances are delimited with the purpose of not detaching the the learning process from the locus in where it occures. After all, "the meaning does not exist within us nor in the outside world, but in the dynamic relationship of living in the world" (WENGER, 1998, p. 54).

Through metaphors and metonymies we notice the reaction of connectionist and autopoietic machines operating within these networks. The language of the ego, symbolic and logical, of the incontestable truths, loses ground to the language of the soul full of doubts that Edgar Morin talks about. The first wants to impose by rhetoric, the second only wants to share memories.

The abduction invents or proposes a hypothesis. The deduction explains the hypotheses, deducing from them the necessary conclusions that can be tested. Induction consists of process the hypotheses' testing (FANN, 1970, p. 10; GHIZZI, 2006). The abduction has similarities with the understanding that we have of intuition. (SANTAELLA, 2004, p. 47). We only understand what we are prepared to interpret. (PEIRCE, 1998, 2010)

Ari Raynsford $^{12}$, Doctor in nuclear engineering degree (EngD) from the Massachusetts Institute of Technology (MIT), based on the full theory of Ken Wilber, intends to fully understand the development and actions of man on Earth. In "Five Minds for the Future" Howard Gardner compares Wilber to Peirce (of Semiotics), who would be "polymaths" (an interdisciplinary team contained in one single man).

We call human machine the ones that manifest, at the same time, as symbolic, connectionist and autopoietic, which do not act in opposition, but in a complementary way. It is from the cooperatively operation of these machines that is intended to build the man of the new Millennium.

The image 5 shows a Klein bottle, which is obtained by bonding two strips of Mobius. It has no borders, left or right, inside and outside. This is a continuum that opens to infinity.

${ }^{12}$ http://namu.com.br/materias/teoria-integral-de-ken-wilber 
Image 5. Human Machine

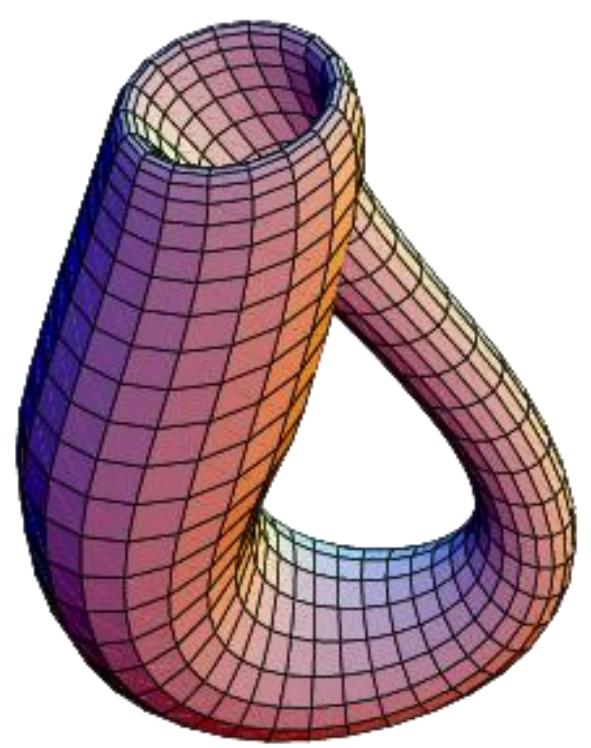

Source: Authors

\section{Conclusions}

I am nothing. I'll never be anything. I couldn't want to be something. Apart from that, I have in me all the dreams in the world.

(Fernando Pessoa)

Teilhard de Chardin ${ }^{13}$ believed that intelligence would be an emergency, due to the complexity of the relationships that an entity established with the universe around it.

According to Roger Martin, we are immersed in mystery. We use our different types of reasoning to extract from this mystery, heuristics. Heuristics are rules that usually works, but not in all circumstances. Algorithms are prescriptions for solving a given problem.

13 TEILHARD DE CHARDIN, P. 1959. L'Avenir de L'Homme. Paris, Seuil, 406 p.

TEILHARD DE CHARDIN, P. 1971. El fenomeno humano. Barcelona, Taurus, $383 \mathrm{p}$. 


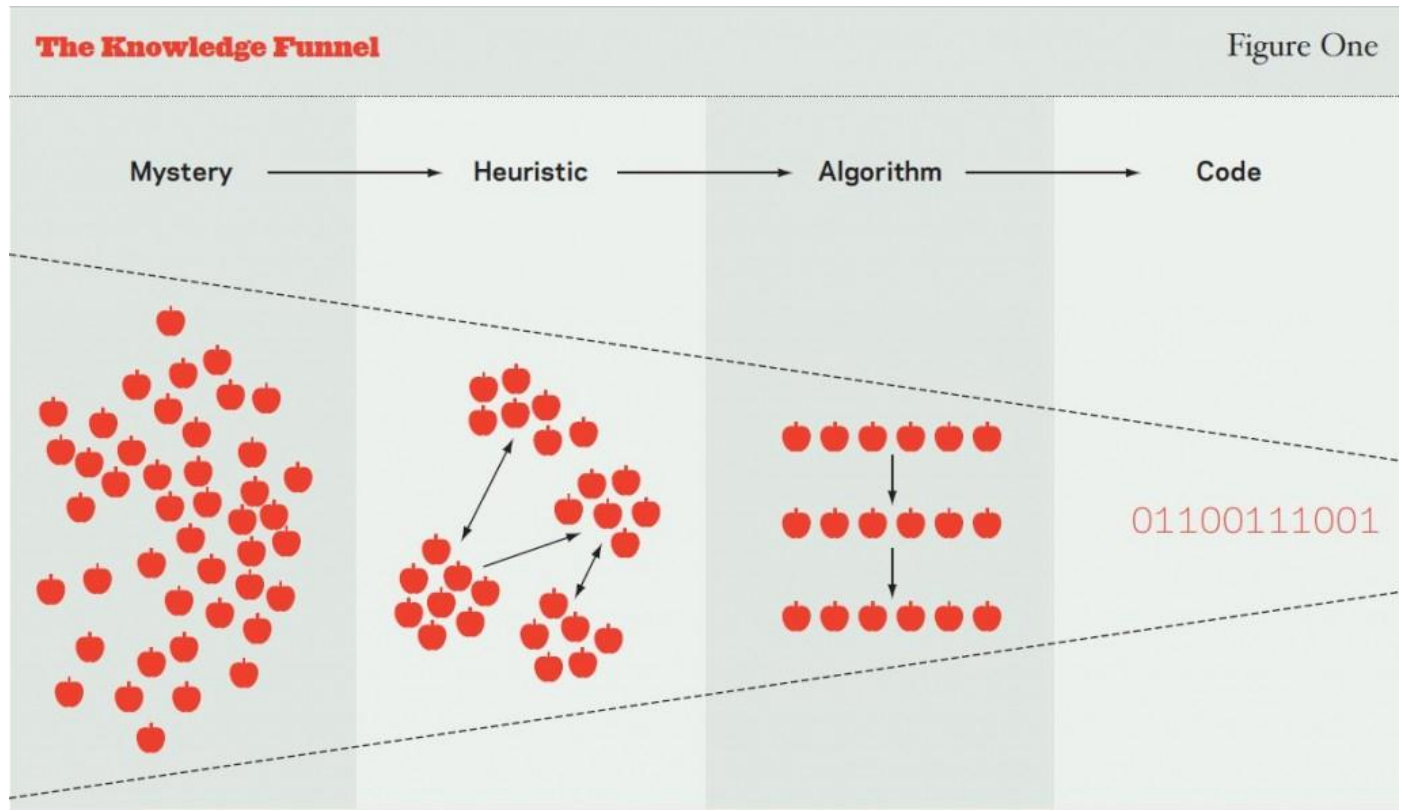

Image 6: The knowledge funnel.

Source: MARTIN (2009), "The design of business: why design thinking is the next competitive advantage".

The symbolic machine is not capable of operating on the mysteries, the most that it is able to do is to establish heuristic and employ algorithms. The connectionist machine adjusts neurons and synapses to adapt itself to the world. The autopoietic machine is a closed system that only opens for internal disturbances.

The education of the past deposited algorithms in the minds of students, truths handed down from generation to generation. Errors that with time make us believe to be truths, said Gilles Deleuze.

The education of the future works with the uncertainties learns about the mystery and teaches us to love it and not fear it. Transforms each student into a wandering metamorphosis that creates worlds and it is recreated in the process.

It is obvious that a new pedagogy is an urgent need, that explores all the possibilities of the machines, symbolic, connectionist and autopoietic that we are. This new pedagogy, but it can not forget that we are much more than that. We are mystery in search of meaning. 


\section{REFERENCES}

BRINK, J. R. fe HADEN, C. R., Eds. The Computer and the Brain: An International Symposium in Commemoration of John von Neumann of Annals of the History of Computing (special number). 1989.

ESTEBAN-GUITART, M.; MOLL, L. C.. Funds of Identity: A new concept based on the Funds of Knowledge approach.Culture \& Psychology, [s.l.], v. 20, n. 1, p.31-48, 1 mar. 2014. SAGE Publications. http://dx.doi.org/10.1177/1354067x13515934.

FANN, K. T. Peirce's theory of abduction . The Hague: Martinus Nijhoff, 1970.

FANN, K. T. Peirce's theory of abduction . The Hague: Martinus Nijhoff, 1970.

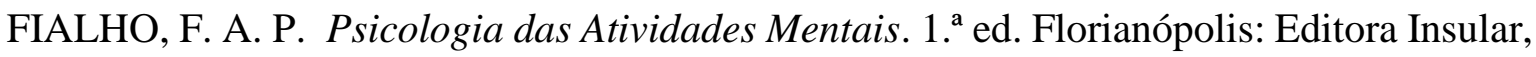
2011.

FREIRE, P. A importância do ato de ler em três artigos que se completam. São Paulo: Cortez, 2005.

GHIZZI, E. B. Arquitetura em diagramas: uma análise da presença do raciocínio dedutivodiagramático no processo projetivo em arquitetura. Cognitio-Estudos, São Paulo, v. 3, n. 2, p. 109-124, jul.- dez. 2006.2 Disponível em: http://www4.pucsp.br/pos/filosofia/Pragmatismo/cognitio_estudos/cognitio_estudos.htm Acesso em: 21 ago. 2010.

ISAACSON, Walter. Os inovadores : Uma biografia da revolução digital / Walter Isaacson. Tradução de Berilo Vargas, Luciano Vieira Machado e Pedro Maria Soares - 1a ed. — São Paulo : Companhia das Letras, 2014.

LAVE, Jean. WENGER, Etienne (1991). Situated Learning: Legitimate Peripheral Participation. Cambridge: Cambridge University Press. ISBN 0-521-42374-0.; first published in 1990 as Institute for Research on Learning report 90-0013

MACHADO, C.J.S. O modelo explicativo de Herbert Alexander Simon sobre a descoberta científica - Revista de Ciência da Informação, 10(1), 2010. Disponível em: http://dgz.org.br/fev10/Art_03.htm acesso em 30 de abril de 2015.

MATURANA, Humberto. A árvore do conhecimento: as bases biológicas da compreensão humana. São Paulo: Palas Athena, 2001.

BARREIRA, Luis História e Historiografia: como Escritas Recentes da História da Educação Brasileira (1971-1988). 1995. 220pp. Tese (Doutorado em História da Educação) UNICAMP, Campinas.

MARTIN (2009), "The design of business: why design thinking is the next competitive advantage". 
PEIRCE, C. S. The collected papers of Charles Sanders Peirce. Ed. de C. Hartshorne; P. Weiss \& A. W. Burks. Cambridge, Harvard University Press, 1931-1958. 8 v. (CP).

The essential Peirce: selected philosophical works. Ed. de N. Houser et al. Bloomington, Indiana University Press, 1992. $2 \mathrm{v}$. . Semiótica. Trad. de J. T. Coelho Neto. São Paulo, Perspectiva, 2000. (Coleção Estudos, 46).

RAMOS, Edla Maria Faust Ramos. Análise ergonômica do sistema hiperNet buscando o aprendizado da cooperação e da autonomia. (1992-1996). 1996. 295 p. Tese(Doutorado em Engenharia de Produção) - UFSC, Florianópolis.

SANTAELLA, L. O método anticartesiano de C. S. Peirce. São Paulo: Editora UNESP, 2004..

SENSE, A. J., BADHAM, R.. Cultivating situated learning within project management practice: A case study exploration of the dynamics of project-based learning. International Journal of Managing Projects in Business, 2008 1(3), 432-438.

SIMON, H. Models of discovery, Dordrecht: D.Meidel Publishing Compagny. 1977. H. A., L'Unité des arts et des Sciences : la psychologie de la pensée et de la découverte, $\quad$ AFCET $\quad$ INTERFACES, $\quad \mathrm{n}^{\circ} \quad 15: \quad 16$. 1984. Row. 1960.

H.A.. The New Science of Management Decision. New York, NY: Harper and

H.; WEBER, R.J. and PERKINS, D.N.. How to invent artifacts and Ideas. New Ideas in psychology, 7(1): 49-72. 1989.

TEILHARD de Chardin, P. 1959. L'Avenir De L'Homme. Paris, Seuil, 406 P.

TEILHARD de Chardin, P. 1971. El fenomeno humano. Barcelona, Taurus, 383 p.

WENGER, E. Communities of practice: learning, meaning, and identity. New York: Cambridge University Press, 1998. 